811.163.41'373"17/18"

811.163.1'373.611

https://doi.org/10.18485/kij.2020.67.2.6

ВАњА Д. МИТИЋ, докторанд*

Оригинални научни рад

Универзитет у Београду

Примљен: 18.10.2020.

Филолошки факултет

Прихваћен: 14.12.2020.

\title{
ТВОРБЕНА АНАЛИЗА ЛЕКСЕМА НАСТАЛИХ КОМБИНОВАНОМ ТВОРБОМ СА СУФИКСОМ -ИЈЕ У СЛАВЕНОСРПСКОЈ ЕПОСИ
}

\begin{abstract}
У раду се анализирају творбени модели којима су настале посрбљене лексеме у другој половини XVIII и првој половини XIX века. На корпусу Посрбица од Орфелина до Вука Велимира Михајловића проучавају се лексеме које су настале у славеносрпској епоси, са циљем да се уоче обрасци губљења, односно опстајања посрбљених лексема у српском језику, водећи рачуна о лингвистичким и ванлингвистичким факторима који су могли утицати на развој језика у овој епоси. На основу поређења са савременим српским и руским језиком, закључујемо да је већина лексема изгубљена због творбених недоследности које су пратиле њихово настајање, односно система творбе који више одговарају руском него српском језику.
\end{abstract}

Кључне речи: посрбице, творбена анализа, творбени модел, туђице, позајмљенице, славеносрпски, рускословенски.

\section{1. Увод}

Српски језик је још од својих почетака био под утицајем страних језика. Велики број туђица довео је до јачања пуристичке струје која се борила против стране лексике у језику. Сматрајући да прилив великог броја страних лексема угрожава српски језик, језички пуристи су прибегли стварању тзв. посрбища, које су представљале домаћи еквивалент страним лексемама. Иако је одређени број посрбица опстао до данашњих дана, већина њих се изгубила, док су стране лексеме опстале. Посрбљавајући лексеме, аутори су се често служили калкирањем. Њихов труд да сведу синтагме на што мању меру резултирао је великим бројем сложеница које нису у духу српског језика. Слабо језичко осећање и не-

\footnotetext{
*vanjamitic95@gmail.com
} 
довољна лингвистичка образованост очигледни су када се посматрају лексеме попут дводугократак, животнословије или чешозубаи. Настале комбинованом творбом, ове сложенице представљају спој творбених форманата који нису уобичајени у српском језику, због чега су се врло брзо и изгубиле.

Комбинована творба представља најсложенији начин творбе у српском језику. У досадашњој литератури о творби речи наилазимо на опречна схватања када је овај тип творбе у питању. Иако научници углавном не признају комбиновану творбу као посебан тип творбе којим настају сложенице, у пракси она постоји, како на синхронијском, тако и на дијахронијском плану. Можемо сматрати да су комбинованом творбом настале оне лексеме које у себи садрже више од два творбена форманта ${ }^{1}$, не рачунајући спојни вокал. Значајан критеријум је и независност делова сложенице: уколико делови не могу постојати као независне лексеме, већ се налазе искључиво у склопу сложенице, можемо говорити о комбинованој творби. Сложенице су често грађене помоћу суфикса -ије, чисто књишког суфикса присутног још у старословенској епоси.

Велики број лексема преузет је из немачког језика. Лексема хитроумије $\left(1838^{2}\right)$ у значењу виц, слабоумије (1793) као превод немачке лексеме kurzsicht. Уместо примера, дат је још један синоним ове лексеме, тупозреније. Лексема крепкоумије (1830) је превод наслова немачке песме Starkeistere, стомакосвареније (1832) је magenelixier, аумозаношеније немачке лексеме schwärmerei. Иако калкирана, ова посрбица је саграђена у духу српског језика: прва основа је именичка, а на другу, глаголску, додаје се суфикс.

Необична је и лексема завичајљубије (1826) уместо стране лексеме патриотизам. Недостатак спојног вокала, као и сугласнички спој -jљ- говори о недостатку доброг језичког осећања њеног ствараоца. Очигледно је да су и каснији аутори приметили да ова лексема није одговарајућа. Наиме, док је лексема завичајљубије посведочена једном, рускословенско отечествољубије (1813), такође синоним овим лексемама, појавиће се још два пута, 1834. и 1837. Закључујемо да је језичком осећању тадашњих учених људи рускословенски облик ипак био блискији него на силу направљена чисто српска лексема.

Остале лексеме чији је други творбени формант -љубије (мудрољубије, честољубије, мирољубије и сл.) уобичајеније су у српском језику, па се могу у нешто измењеном облику ${ }^{3}$ пронаћи и у савременом српском језику. Како Клајн истиче, међу сложеницама са данашњим суфиксом -је највише је примера управо са глаголом љубити. Наводи примере попут родољубље, слободољубље, властољубље (Клајн 2003: 60). Лексема честољубије у значењу амбиција преузета је из руског језика, где се до данас одржала у истом значењу. Лексема је временом прилагођена српском језику, те данас имамо облик частољубље. Белић

\footnotetext{
${ }^{1}$ Творбеним формантом сматрамо оне јединице које учествују у стварању нове лексеме: творбене основе и афиксе.

${ }^{2}$ У загради се налазе године када су наведене лексеме посведочене.

${ }^{3}$ Суфикс -је заменио је првобитно -ије, тако да је се слово $j$ нашло иза билабијалног 6 , што је довело до јотовања. На овај начин настао је савремени облик -љубље.
} 
наводи да је ова лексема преузета како би се извршила десинонимизација међу лексемама частољубље и понос, које су у српском језику сматрани синонимима (Белић 1933: 15).

Именица атмосфера има три синонима: воздухокружије (1826), воздухокруженије (1835) и парокружије (1844). Занимљиво је да је у двема варијантама које у себи садрже лексему ваздух, односно воздух, први део сложенице, возду$x o-$, написан са рускословенском вокализацијом полугласника. Претпостављамо да српском народу ова варијанта није била необична јер је и у руском језику сложеница са првим делом воздухо- било пуно.

Облици черножелчије (1800), черножучије (1804) и црножучије (1826) три су облика једне исте лексеме и значе меланхолија 4 . На овом примеру можемо пратити развој језика од рускословенског ка народном. У облику черножелчије примећујемо вокализацију старословенског меког полугласника до $e$, као и вокално $л$ у типично руском маниру. Четири године касније долази до делимичног посрбљавања ове лексеме: иако је руска вокализација остала, вокално л прешло је у $y$, док најзад, 1826. године, није забележен потпуно српски облик, црножучије. Занимљиво је да је облик ирно- у ову лексему доспео из српског народног језика, а не из српскословенског, што говори о све већем утицају народног језика на тадашњи књижевни. Још један синоним лексеме меланхолија је тјашкосердије (1800). Ова лексема је такође преузета из руског, што запажамо на основу руске деназализације и групе -ер-. Умозрение (1808) преузето је из руског језика уместо стране лексеме теорија, а ово значење у руском језику се одржало до данас. У српском језику је пак дошло до десинонимизације, па је до данас опстала једино лексема теорија. Свободомислије (1816) је лексема која је преузета из руског језика у XIX веку. У српском ју је заменила лексема либералност, док је у руском опстала до данас. Посрбица лицедејствије у руском језику има еквивалент лицедейство. Страни еквивалент у српском језику је мимика, док је у руском ова лексема дефинисана као театральное представление (ТСРЈ: 810). Дакле, у руском језику је значење остало везано за позориште, док је у српском проширило значење и пренело се на све сфере. За лексему државина, односно немачку варијанту besitzer, пронађен је руски еквивалент притјаженије. Ова лексема није ни прилагођена српском језику, већ је остала у изворном, руском облику, са групом-ја- на месту српског -e-.

Иждивеније и данас постоји у руском језику, док је у српском замењено страном лексемом стипендија. Ипак, значење се донекле изменило. Док је данас стипендија новчана надокнада која се даје као помоћ ученицима или студентима (РМС 6: 1025), у руском је иждивеније „Обеспечение неработающего (как правило, неработоспособного: больного, престарелого, несовершеннолетнего) средствами, необходимыми для существования" (ТСРЈ: 576). Дакле, и овде је дошло до извесне десинонимизације.

\footnotetext{
${ }^{4} \Phi$ p. la melancolie
} 
У основи лексемежалкоигрије (1809, трагедија), примећујемо основу жалко-, која је преузета из руског језика. Осим тога, као синоними лексеме трагедија јављају се још и синтагме жалосна игра, жалосно позориште и жалосно позорје 5 . Ипак, све ове лексеме и синтагме су се изгубиле, остављајући једино грецизам трагедија у употреби.

Лексема воспрјановеније дата је као превод латинског expergefatio, а објашњена је као напрастноје пробужденије от сна. Видимо да је и ова лексема преузета из руског језика, и то на основу руске варијанте префикса воз-, као и на основу вокализације некадашњег назала до -ја-. И у лексеми општевоспријатије (1793) постоји руски формант воз-. Ово је хибридна творевина која не одговара творби речи у српском језику. Наиме, у руском језику и данас постоји лексема настала префиксацијом, восприятие. Посрбица чији други формант чини управо ова лексема направљена је тако што је на већ сложену лексему воспријатије додат први формант опште-. На овај начин добијена лексема има префикс као средњи формант, што се не уклапа у творбене стандарде.

\section{2. Посрбљавање назива научних дисциплина}

У другој половини XVIII и првој половини XIX века јавило се појачано интересовање за науку, што је изазвало појаву нових научних дисциплина и, природно, потребу да се оне именују. И овде су се јавили покушаји да се страна терминологија посрби, међутим, врло брзо су се посрбљене лексеме изгубиле, док су страни термини опстали до данас. Маријана Киршова истиче да је стварање терминологије процес који, иако базиран на истом творбеном моделу по коме се ствара лексика из осталих области, процес који се намерно регулише ради што лакшег остваривања комуникације, због чега се користи међународни лексички фонд (Киршова 1990: 180).

Лексеме које у свом другом делу садрже формант -слов- на који се додаје суфикс -ије бројне су у славеносрпском језику. Преведене на савремени српски језик, већина њих означава научне дисциплине. Примарно значење лексеме ботаника у Речнику српскога језика је „наука о биљкама” (РСJ: 100), лексеме физика „природна наука која проучава материју, њена својства [...] и законитости по којима се ове појаве збивају” (РСЈ: 1405), лексеме минералогија „наука о металима" (РСJ: 697) итд. Све ове лексеме имају заједничку архисему: наука. Можемо закључити да је формант -словије у славеносрпским лексемама синониман лексеми наука. Говорећи о посрбицама, ово потврђује и Гордана Штасни: „Сложенице овога композиционог типа садрже на првом сложеничком месту именичку основу речи којом се именује основни премет [sic!предмет] проучавања одређене науке а семантички еквивалент другом сложеничком делу словије јесте наука" (Штасни 2013: 367).

\footnotetext{
${ }^{5}$ Познато је да је и Ј. С. Поповић своје трагедије називао жалосним позорјима.
} 
Лексеме коренословије и художнословије су синоними лексеме етимологија, односно етимологизирање. Лексема художнословије, преузета из рускословенског језика, овде је дата као посрбљена варијанта лексеме етимологија. Ова лексема јавља се још једном, и то као страна варијанта посрбице истинословије. Дакле, иста лексема се јавља и као страна лексема која се морала посрбити, и као посрбица. Ово потврђује недоследност и недостатак норме, чак и имплицитне, у славеносрпској епоси.

Примећујемо још рускословенских облика: нравословије (етика), и јестествословије (физика). У огледној свесци Речника славеносрпског језика примарно значење лексеме јестество је природа (РслсЈ: 143). Нису, ипак, све лексеме које у себи садрже јединицу -словије- називи научних дисциплина. Ове именице могу имати и основу -ученије. Осим лексеме нравоученије $(1790$, морал), која нема ово значење, све именице које садрже овај формант означавају називе наука: телоученије (1833, анатомија), јазикоученије (1818, граматика), земљоученије (1833, географијаб).

Домаћи синоними лексеме астрономија су звездочатије (1805), звездочетије (1766) звездочтеније (1814) и звездозаконије (1790). Најстарија лексема, из 1766. године, има руску вокализацију полугласника, која касније бива замењена српском. Интересантно је да најмлађа лексема, из 1814. године, има највише потврда у Посрбицама, из чега можемо претпоставити да је највише одговарала језичком осећању говорника српског језика.

Термин травоиспитаније (1817) означавала је ботанику, а исте године се појавила и лексема каменоиспитаније као синоним минерологији. У Посрбицама је забележен и синоним лексеме каменоиспитаније, каменословије, који се појавио две деценије раније. Како је за обе лексеме забележена једна потврда, немогуће је утврдити да ли се једна јављала чешће него друга. До данас су се обе изгубиле.

Још један термин који је ишчезао из српског је домаћа реч за акцеенат, глаcoyдареније (1800). Ана Мацановић пак наводи да у овој епоси лексема гласоудареније ипак није означавала само акценте, већ и различите ортографске и прозодијске знаке (Мацановић 2018: 152). Она такође наводи да је пре потпуног ишчезавања овог облика из српског језика дошло до његовог понародњавања, чиме су добијени облици гласоударање и гласоудар (Мацановић 2018: 403). Такође, лексема правоглаголаније, која је домаћи синоним грчкој ортоепији, нестала je. А. Мацановић наводи да је ова лексема заправо калк, буквални превод грчког термина (Мацановић 2018: 44), а како калкови врло често не одговарају стању у језику на који се преводе, није необично што се и ова лексема изгубила.

Земљемерије у значењу геометрија јавља се 1766. године. Примећујемо спојни вокал -е- после меког -љ-, што се у савременом српском готово изгубило.

${ }^{6}$ Учење о телу, учење о језику, учење о земљи - ове лексеме се могу превести у одговарајуће глаголске синтагме, што је у складу са очекиваним начином творбе. 
Овај спојни вокал је остао само у неколицини лексема, док је у славеносрпској епоси био врло чест.

Са прилогом у првом делу постоји именица млогосојузије, што је домаћа варијанта интернационалном термину полисиндентон (polysinthenton). Слично, термин асиндентон (asynthenton) такође има своју славеносрпску варијанту, која гласи бесојузије .

Лексеме са формантом -твореније јављају се спорадично током XIX века. Године 1805. појавила се лексема стихотвореније (поезија), која се потпуно уклопила у модел творбе оваквих сложеница: то је глаголска именица која представља спој именице стих и глагола творити, са суфиксом -ије који се у глаголским именицама најчешће и јавља.

Још две лексеме са формантом -твореније налазе се у Посрбицама: довлетвореније (1803, сатисфакција) и олицетвореније (1841, персонификација) са префиксом, двема коренима и суфиксом. Како је персонификащија научни термин, природно је што домаћа реч није опстала, с обзиром на то да термини у највећем броју случајева припадају интернационалној лексици.

Лексеме са формантом речије- биле су релативно честе у српском језику XVIII и XIX века. Лексема сличноречије (1842) јавља се у Посрбицама у значењу каденца. Ипак, још 1813. године Лука Милованов назива своје реформаторско дело Опит наставлења к Србској сличноречности и слогомерју или просодии. Иако је суфикс другачији, из творбене перспективе може се сматрати да су ови суфикси синоними: оба означавају углавном апстрактне именице и углавном се додају на глаголске именице. Код Милованова пак ова лексема не значи каденцза, већ означава версификацију. Можемо, дакле, закључити да, иако су суфикси синонимни и основе потпуно једнаке, лексеме у овим епохама не морају нужно имати исто значење, већ је дозвољена слобода у интерпретацији и стварању нових лексема.

Реторика односно елоквеничја некада се звала красноречије. У првом делу сложенице је придев, уместо очекиване именице. Слично је и у случају лексеме једноречије, где је у првом делу сложенице основа настала од основног броја један. Још један термин, иноречије (алегорија), такође се изгубио, као и његов синоним разноглаголаније.

\section{3. Творбене недоследности}

Иако је у Посрбицама забележено чак шест потврда лексеме четвороуглије (1815), ова лексема није могла опстати у савременом српском језику, јер се противи типичним творбеним механизмима. У другом делу ове сложенице, уместо очекиваног и уобичајеног глагола, налази се именска реч, односно именица угао. Слична ситуација је и са лексемом четвероћошије. Међу овим лексемама, иако је прва основа готово једнака, примећујемо фонемску дублетност: док је у првој лексеми основа четворо-, у другој је четверо- ${ }^{7}$.

\footnotetext{
${ }^{7}$ Облик четверо- примећујемо и у лексеми четверогласије.
} 
Тримесечије у значењу квартал први пут се појављује 1847. године. Данас је страни синоним потпуно потиснуо посрбљену лексему, што је и очекивано, с обзиром на то да творбени модел у коме је основни број три основа првог дела сложенице није типичан за српски језик. Наиме, Клајн наводи да облици дво- и тро- у првом делу ових сложеница представљају скраћену верзију збир-

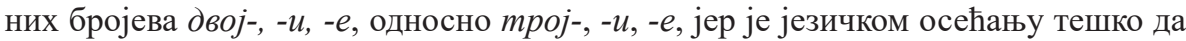
прихвати сегменте дв- и mp-, који су мањи од слога (Клајн 2002: 76). Такође, овде изостаје и спојни вокал, па се друга основа, настала од именице месеи, директно додаје на број три. Основни број је основа и код лексема једнокончаније, једнозвучије и једноначалије. Постоје и сложенице са бројем два у основи: двобрачије и двосупружије, које су синонимне лексеми бигамија, па ни оне нису опстале у савременом српском језику. Слично, у српском је постојала лексема многобрачије у значењу полигамија, која је ишчезла до данас ${ }^{8}$.

Лексеме са предлогом против као првом основом сложеница, попут противочувствије (1846), противострастије (1803), противоположеније (1838) и противодејствије (1802) нису уобичајене за српски језик. Наиме, предлог у сложеници, нарочито оној насталој комбинованом творбом, врло је редак случај у језику. Клајн наводи искључиво специфичне примере ових именица, попут побратим, поочим и сл. (Клајн 2002: 34).

Од лексема чији други део гласи -описаније издвајамо светаописаније (1844, космографија). На месту на коме се обично налази спојни вокал примећујемо фонему $a$. С обзиром на то да овај спојни вокал не постоји у српском језику, можемо закључити да први део сложенице заправо представља именицу свет у генитиву, што није уобичајено у творби речи српског језика. Ако упоредимо са другим лексемама које у себи садрже формант -описаније (земљеописаније, народоописаније, животоописаније и државоописаније), схватамо да је наведена лексема једина која је дата у генитиву, из чега закључујемо да је ово било неуобичајено и у славеносрпском периоду.

Лексеме самодржавије и земљедржавије нису у складу са стандардима по којима се обично у лексеме настале комбинованом творбом. Наиме, уместо глаголске основе, други творбени формант чини основа настала од именице држа$в а$ на коју се додаје суфикс -ије.

Од неколико лексема које у себи садрже формант -положеније, творбено је најинтересантија равноположеније (1837, паралелизам). Прва њена основа настала је од прилога равно, што је неуобичајено. Може се поставити питање да ли је основа преузета по узору на именицу раван, али у том случају ова лексема вероватно не би значила паралелизам, већ би се ограничило на термин који би припадао сфери геометрије. Први формант равно- има и лексема равноноћије (1844).

Ногоболеније (1790) је сложеница која је настала од синтагме болети нога. У оваквим спојевима очекујемо да је први формант у некадашњој синтагми

${ }^{8}$ У Посрбицама је забележен и облик многоженство, али и он је нестао из српског језика. 
имао функцију правог објекта, док овде то није случај, већ је именица нога овде била субјекат. Дакле, творбени модел ове сложенице не одговара уобичајеном, па се она морала изгубити. Слично је и са лексемом образорезаније (1815) и плодородије (1845), где су први форманти вршили функцију неправог објекта.

Иако је други део сложенице главноуправленије (1831, командирство) настао од глагола управљати, први део није именица, коју очекујемо на овом месту, већ прилог главно, због чега се, као и остале овакве именице, изгубила.У првом делу сложенице својељубије (1816, егоизам) налази се заменица свој, што је неуобичајено и несвојствено српском језику. У свега неколико лексема, попут својеручни и својеврстан заменица свој налази се у првом делу сложенице. Ниједна од ових лексема није именица. Исти је случај и са заменицом себе, која представља прву основу лексеме себечувствије (1939).

Уместо лексеме ц̧ентар 1861. године јавила се лексема средоточије. Иако је ова лексема нестала из српског језика, и даље постоји глагол усредоточити ce, чије је примарно значење у РМС „скупити, сабрати, обратити (сву пажњу, све мисли, сву активност) на једну ствар, у једном правцу, концентрисати.” (РМС 6: 593 ) С обзиром на то да је један од творбених форманата глагола усредоточити се префикс $y$-, можемо рећи да јеовај глагол настао префиксацијом од исте основе као и именица средоточије.

За настанак лексеме скотооградије (зодијак) постоји објашњење: како значи зодијак, а знаци зодијака у већини случајева носе имена животиња, први део, ското-, руска је реч за животињу ${ }^{9}$, док је основа -оград- и у руском и у српском језику задржала значење које данас има лексема ограда. У Посрбицама је наведено да, како постоји 12 знакова зодијака за 12 месеци у години, они морају бити „ограђени”, јасно разграничени.

У лексемама самоправленије (1841), правоправленије (1790) и народоправленије (1834) доследно не долази до јотовања усненог сугласника. Рукоудареније (1793) и рукоплесканије (1794) синоними су и значе аплауз. Ове сложенице настале су превођењем глаголских синтагми ударати рукама и пљескати рукамау једну сложену лексему. Тежња да се српски језик ослободи непотребних сложеница заслужна је за нестанак ових лексема из савременог српског језика, иако је овакав модел творбе уобичајен и данас.

Лексема путешествије била је врло уобичајена у славеносрпском језику. Облик наведен у Посрбицама је карактеристичан за руску редакцију, али је јако уобичајен на српским просторима. У огледној свесци Речника славеносрпског језика ова лексема преведена је као путовање, а, иако је прва потврда у Посрбицама из 1838. године, у Речнику су наведени примери из 1799, 1814. и 1830. године, тако да се ова лексема заправо јавља много раније (РСлсЈ: 242).

${ }^{9}$ „СКОТ, -а, м. 1. Сельскохозяйственные млекопитающие животные. Домашний с. и птица. Крупный рогатый с. Племенной с. Молочный с. Рабочий с. Загон для скота. 2. перен. То же, что скотина (во 2 знач.) (прост, бран.). С. ты этакий! II прил. скотный, -ая, -ое (к 1 знач.) и скотский, -ая, -ое. Скотный двор. Скотский вагон” (ТСРЈ: 1818-1819). 
Праводушије и великодушије не уклапају се у типичне начине творбе српског језика. Уместо очекиване глаголске основе, на месту другог творбеног форманта јавља се основа која је настала од именице душа, а први формант чине основе настале од придева прав и велик на месту на коме бисмо у типичном случају очекивали именицу.

Лексема обезбежденије (1815, гаранщија) у измењеном облику обезбеђење опстала је до данас, али је и значење донекле измењено. Овде је дошло до десинонимизације, па су се обе именице очувале, али у различитим значењима.

Иако лексема малолетије (1814) данас више није у употреби, ни њен страни синоним миноренство није се задржао у српском језику. Данас за означавање младе особе која није пунолетна не постоји једна лексема, већ се користи именичка синтагма малолетна особа. Ипак, можемо сматрати да је придев малолетан изведен од именице малолетије, тако да се ова посрбица ипак посредно задржала у српском језику. Дакле, видимо да су неке посрбице, посредно или непосредно, остале у српском језику до данас. Ово истиче и Стана Ристић:

„Попуњавајући концептуалне празнике [sic! празнине] у лексичком систему ондашњег књижевног језика многе стране речи из фонда опште лексике добиле су место у његовом централном систему и то место држе и данас у савременом српском књижевном језику (што се може видети из наведених примера)" (Ристић 1996: 184).

Михајловић у Посрбицама наводи облик лексеме државосложеније, док у примерима које наводи уз ову лексему, она гласи державосложеније, са руском вокализацијом. Исти је случај и са лексемом државоустројеније, односно державоустројеније.

Лексему вероисповеданије (религија) можемо преточити у глаголску синтагму исповедање вере. Осим ове, књижевне варијанте, у Посрбицама је забележена и варијанта вероисповедање. Интересантно је да је прогресивнија лексема, са суфиксом -je, забележена 1814. године, годину дана пре лексема са суфиксом -ије. На основу ових примера можемо закључити да се српски језик није развијао једнолично, већ да се у овом периоду пише слободно, у складу са језичким осећањем и ставовима самих аутора.

Лексема благочиније (1790, полиција), јавља се и 1843. године и у значењу доброчинство. Михајловић ова два значења не представља као хомониме, већ их наводи као два значења исте лексеме. Могуће је, дакле, да су некада ове лексеме биле много ближе него данас, када је дошло до њихове потпуне десинонимизације.

Благодејаније (1794) представља превод латинског израза ius foeudalis. У огледној свесци Речника славеносрпског језика ова лексема дефинисана је као добро дело, доброчинство, а осим облика благодејаније наведен је и дублетни облик благодјејаније (РСлсЈ: 55). Ово је само једна у низу именица које у себи садрже фомант благо-. Ове именице су биле веома честе у славеносрпској епоси, а један од разлога за то је појава некролога у часописима, где сама природа текста диктира велики број црквенословенских сложеница, међу којима су најчешће управо оне са формантом благо- (Милановић 2013: 203). 
У Посрбицама су потврђене три сложенице настале сложено-суфиксалном творбом које у себи садрже сегмент -властије: сродствовластије (1843), својевластије (1848) и боговластије (1848). Примећујемо да се све лексеме које у себи садрже формант -властије јављају касно, у петој деценији XIX века. Ово се може повезати са историјским околностима у датом тренутку. Наиме, прва потврда лексема са формантом -властије забележена је 1843. године, у бурном периоду српске историје. Политички сукоби и непоштовање Турског устава довели су до смене династије Обреновић династијом Карађорђевић 1842. године. Овакве прилике у земљи захтевале су писање о њима, што је са собом донело и појаву нових речи у вези са влашћу и политичким приликама.

Лексема безбедије (1813, сигурност) настала је префиксално-суфиксалном творбом и састоји се из три морфеме: префикса без-, корена -бед- и суфикса -ије. Како се лексема која је данас у употреби, безбедност, јавила још 1803. године са истим значењем, примећујемо да савременији суфикс -ост није одмах однео превагу над данас готово ишчезлим суфиксом -ије, већ су једно време били у равноправној употреби. У Посрбищама су забележене по две потврде ових облика, и то у истом делу, са само годином разлике: безбедије 1813, а безбедност 1814. године. Уочавамо произвољност и недостатак правила при употреби лексема.Лексеме безвластије (1846) и безвладије (1842) су синоними лексеме анархиј $a^{10}$. Настале су префиксално-суфиксалном творбом, са истим префиксом и суфиксом и различитим коренима. Лексеме настала префиксално-суфиксалном творбом са префиксом без- и суфиксом -ије су безуздије $(1837$, тиранија) и безбожије 11 (1772, атеизам).

Дублетни облици сагласије (1846) и согласије (1767) у значењу хармонија ${ }^{12}$ јављају се у великом временском распону. Природно, облик са рускословенским со- старији је од облика са српскословенским префиксом $c a-$. Лексема $c a-$ гласје јавља се и у РМС, а дефинисана је на следећи начин: складност звукова, сазвучје; сагласност (РМС 5: 604). Дакле, примећујемо да лексема хармонија није наведена као један од синонима ове лексеме. Међутим, у Лалевићевом речнику синонима као синоним лексеме сагласје дата је само лексема слога. Дакле, иако лексема није изгубила значење под којим је ушла у српски језик, дошло је до развоја полисемантичке структуре.

Лексеме ухљебије и прихљебије, иако облички сличне, имају различито значење. Лексема ухљебије (1814), синоним је за пензију, док прихљебије (1808) одговара галицизму апанажа. Дакле, обе лексеме односе се на новчана примања. Закључујемо да се корен лексема ухљебије и прихљебије метафорички изједначава са новцем као средством за набављање основних животних потреба, чији је прототип хлеб, односно хљеб.

\footnotetext{
${ }^{10}$ Осим ових, у истом значењу постоји и лексема безвладство.

${ }^{11} \mathrm{У}$ Посрбицама се јавља и антоним ове лексеме, свебожије, изграђен по сличним творбеним принципима, иако је прва основа заменичка уместо префикса без-.

12 Лексема согласије осим значења хармонија има и значење симфонија.
} 
Лексема уразуменије је лингвистички термин који значи синегдоха. Јавља се 1821. године у Руководству к словенском красноречију... Аврама Мразовића. Овај облик Мразовић је преузео из рускословенског језика, што је било типично за тадашњу лингвистичку терминологију:

„У првим деценијама 19. века приметан је велики утицај руске и рускословенске језикословне терминологије. Под утицајем руских и рускословенских граматика, приметна је знатна рускификација језикословне терминологије код Срба, посебно у делима А. Мразовића, П. Соларића, М. Видаковића, Д. Милаковића и Ј. Поповића” (Мацановић 2018: 408).

Две лексеме са различитим префиксима и кореном -равн- јављају се крајем прве половине XIX века, док се једна појавила крајем XVIII века: изравненије (1841, трансакција), поравненије (1846, од лат. contemplatio) и уравненије (1794, компарација).

Лексеме узмуштеније, односно возмуштеније представљају дублетне, посрбљене облике лексеме револуиија. Иако је лексема возмуштеније (1813), очекивано, старија, потврђена само годину дана пре појаве лексеме узмуштеније. И овде је рускословенски префикс воз- измењен, прелазећи у облик типичан за српски народни језик, уз-. Такође примећујемо да се рускословенски облик након појаве народног више не појављује, док српска лексема наставља да се јавља у делима све до 1846. године.

Лексема безиарствованије (1793, анархија) настала је комбинованом творбом, са фомантима без-, -царств-, -ов-, -ан- и -ије-. На овој лексеми можемо приметити сву сложеност лексема насталих комбинованом творбом: префикс, инфикс и суфикси удружени стварају домаћу лексему која је сложенија од стране, због чега је страна лексема опстала у српском језику, док се домаћа изгубила. Слично је и код лексеме беспристрастије (1791).

Код лексеме велесилије (1817, енергија) Михајловић упућује и на лексему благогласије (хармонија, симфонија). Како данас у српском језику постоји лексема велесила, очекивано би било да је и у славеносрпском велесилије имало бар слично значење. Ипак, у РСЈ префиксоид веле- дефинисан је као „први део сложенице који показује појачавање у великој мери онога што се казује основном речју” (РСЈ: 129), док је примарно значење лексеме сила „сваки узрок који изазива промену брзине или смера кретања неког нееластичног, крутог тела” (РСJ: 1195), тако да можемо закључити да се лексема велесилије ипак може повезати са префиксоидом веле- и именицом сила.

Лексема возмездије и данас постоји у руском језику, а у речнику ТСРЈ дефинисана је као „Отплата, кара за преступление, за зло. Справедливое в. Неотвратимое в.” (ТСРЈ: 204). У Посрбицама пак наведена је у значењу пензија. Видимо да ове две лексеме у различитим језицима имају слично значење. Заједничка им је архисема новац, али у руском језику је то новац који одређена особа даје као казну, док у српском, односно славеносрпском, особа прима новац због својих заслуга. Ова појава се у лексикологији назива енантиосемија.

Данашње сазвежђе се некада јављало у два лика: созвездије (1767) и сазвездије (1846), а на рускословенски начин, са префиксом со- и групом -uт- је написана и лексема сообраштеније (1807). 
Поред терминасочиненије 13 (1794, синтакса), А. Мацановић бележи и облик словосочиненије, односно словосачиненије у истом значењу (Мацановић 2018: 79), али у Посрбицама се ови облици не појављују. Као што је случај са свим осталим терминима, касније се домаћа варијанта изгубила, док је страна опстала до данас.

У лексеми кругообраштеније (1800, цүиркулација) примећујемо црквенословенску групу -шт-, која ће касније у српском језику бити замењена народним- $\hbar$ Ово видимо и у лексемама сокраштеније (1794), созакљатије (1816), созаклетије (1814) и сазаклетије (1815). Интересантно је да је најмлађи облик заправо облик који је преузет из руског језика, са префиксом со- и деназализацијом до -ja-.

Лексеме соведеније (1793) и поведеније (1856) настале су у временском распону од преко 60 година, па видимо да се творбени модел није много променио од почетка славеносрпске епохе до њеног краја.

Лексема сабрдије (1845, фр. groupes de montagnes) данас би се могла превести као планински венац. Српскословенски префикс $c a$ - овде постоји да би нагласио да је у питању скуп, група планина. Иако данас не постоји лексема која би имала значење једнако овој, ни она се није одржала, већ њено значење интерпретирамо синтагмом.

Сложена именица отделије (1799) у складу је са правилима старог, предвуковског правописа. До данас се ово променило, па постоји глагол оделити, у коме је једначење сугласника по звучности извршено. Ипак, у лексеми рашчланеније (1802) догодиле су се чак две промене, једначење сугласника по звучности и једначење сугласника по месту творбе, тако да ни овде не можемо пронаћи доследност када је славеносрпски језик у питању.

Лексема приноштије (1812) означава конак, односно коначиште, преноћиште, преноћење (РСJ: 545). Дакле, у савременом српском има везе са лексемом ноћ. У Посрбицама је наведен облик са групом -шт- уместо - $\hbar$-, што није српски манир, али није био ни необичан у време конкуренције различитих идиома. Ово се десило и код лексеме похиштеније (1815), а слично је и у случају лексеме прохлажденије (1793), где група -жд- долази на место српског -ђ-, као и у лексеми междуцарствије (1801).

Лексема претхрамије (1851, атријум) означава део који претходи главном делу зграде. Корен лексеме претхрамије је -храм-, што и у српском и у руском језику означава место на коме се врши богослужење, цркву, док атријум означава било које предворје. Из примера који потврђује ову лексему у Посрбицама јасно да је и овде лексема атријум употребљена да означи предворје храма ${ }^{14}$. Може се поставити питање да ли је овде реч о неадекватном преводу стране лексеме, или је касније дошло до десинонимизације у српском језику.

${ }^{13}$ Одредница у Посрбицама заправо гласи сочиненија, али готово са сигурношћу можемо рећи да је у питању штампарска грешка, јер се у примеру испод одреднице наводи облик сочиненіе, а и А. Мацановић бележи облик са фонемом е (Мацановић 2018: 48). (atrium).

${ }^{14}$ Цркве найдревніи Хрістіана на подобіе храма Солпионовогъ, у комъ е было предхраміе 
Захотеније (1801) и захтеваније (1801) синоними су и означавају каприц. Облик прилагођен народном језику, захтевање (1845) јавља се тек када је народни језик почео да заузима значајно место у нашој писмености.

Лексема наличије и данас постоји у српском језику. Црквенословенски суфикс -ије замењен је народним -је, као и у другим лексемама, али осим тога, других промена у самом облику лексеме нема. Ипак, значење се променило, па је тако некад ова лексема означавала форму, док је данас у РСЈ примарно значење ове лексеме „задња, друга страна нечега (обично мање изложена погледу, мање уочљива, мање важна и сл.)" (РСJ: 761), а значење из Посрбища се не појављује ни у једном секундарном значењу.

Војни термин окрилије (1838) састоји се од префикса о-, корена -крил- и суфикса -ије. Иако и данас именица окриље постоји у српском језику, значење је измењено, па у РСЈ и РМС не постоје значења која су у вези са војском и војном терминологијом (РСJ: 856; РМС 4: 110). Још једна лексема са префиксом $o$ - је омрзеније (1790, антипатија). Она се до данас потпуно изгубила, али њени трагови се виде у постојању глагола омрзнути, који је и даље у активном лексичком фонду говорника српског језика.

Преиначеније (1808, реформа) и данас постоји у српском језику у измењеном облику, али се јавља далеко ређе него лексема реформа. Могуће је да ће временом страна реч потпуно истиснути посрбицу, као што се у већини случајева и догодило.

Значење именице подножије $(1830$, nатос) је данас измењено. Иако имају неке заједничке семе, данас се подножје односи на „доњи део неког предмета” (PCJ: 936), док патос можемо заменити синонимом под. Поднебесије (1812, клима) има и варијанту са другим суфиксом којим се граде апстрактне именице: поднебесност (1835). Обе варијанте су нестале, јер представљају вештачки направљену сложеницу од предлошко-падежне конструкције, док је лексема клима проста и у потпуности прилагођена српском језику. Лексема подстолије (1794) се некада користила да означи интерпункцијски знак, тачку и запету. Касније је ова лексема нестала, док је синтагма опстала до данас.

Са формантом -верије у Посрбицама су забележене три лексеме: сујеверије (1846), воверије (1841) и бујеверије (1816). Све лексеме су забележене у XIX веку. У лексеми воверије видимо руску вокализацију префикса въ-, на основу чега закључујемо да је он сматран српским и у време саме Вукове реформе.

Испитујући творбене моделе посрбица насталих комбинованом творбом са суфиксом -ије у српском језику, приметили смо много творбених недоследности и мањак „доброг” језичког осећања аутора ових лексема у славеносрпском периоду. Разлог томе вероватно лежи у недостатку норме, како експлицитне, тако и имплицитне. Иако су ове лексеме махом изгубљене, за лексикологе и историчаре језика оне су данас значајне јер пружају увид у стање у коме се српски језик налазио у периоду без норме, па су Михајловићеве Посрбице још увек непресушан извор информација о српском језику, који отвара могућност за многа будућа истраживања. 
Извори

Михајловић 1982: Велимир Михајловић, Посрбище од Орфелина до Вука.I том (Б-O), Нови Сад: Матица српска.

Михајловић 1984: Велимир Михајловић, Посрбице од Орфелина до Вука.ІІ том (П-Ш), Нови Сад: Матица српска.

\section{Литература}

Белић 1933: Александар Белић, „О ’Частољубљу”, Наш језик, I, 12-15.

Киршова 1990: Маријана Киршова, „Глаголске именице са суфиксом -ње као термини у савременом књижевном српскохрватском језику", Научни састанак слависта у Вукове дане, 18/1, 179-190.

Клајн 2003: Иван Клајн, Творба речи у савременом српском језику. Други део: суфиксаиија и конверзија, Београд - Нови Сад: Завод за уџбенике и наставна средства - Институт за српски језик САНУ - Матица српска.

Мацановић 2018: Ана Мацановић, Српска језикословна терминологија у 19. веку, Београд: Институт за српски језик САНУ.

Милановић 2013: Александар Милановић, Језик весма полезан, Београд: Друштво за српски језик и књижевност Србије.

Ристић 1996: Стана Ристић, „Неке карактеристике стране лексике у језику предвуковског времена (на корпусу Грађа за речник страних речи у предвуковском периоду, I том - Велимира Михајловића)", Научни састанак слависта у Вукове дане, 25/2, 177-186.

PMC: Речник српскохрватског књижевног језика, I-VI, Нови Сад/Загреб: Матица српска/Матица хрватска, 1967-1976.

PCJ: Речник српскога језика, Нови Сад: Матица српска, 2011.

РСЛСЈ: Речник славеносрпског језика, огледна свеска, Нови Сад: Матица српска, 2017.

ТСРЈ: Сергей Иванович Ожегов/Юльевна Наталия Шведова, Толковый словарь русского языка, Российская академия наук/Институт русского языка имени В.В. Виноградова, 1996.

Штасни 2013: Гордана Штасни, „Називи наука у 'Посрбицама од Орфелина до Вука"', Кюижевност и језик, LX/4-5, 363-380. 
Vanja D. Mitić

\title{
COMPONENTIAL ANALYSIS OF THE LEXEMES FORMED THROUGH COMPOUNDING WITH THE SUFFIX -IJE IN THE SLAVONIC-SERBIAN EPOCH
}

\begin{abstract}
Summary
This paper analyses word-formation models through which Serbianised lexemes were formed in the second half of the 18th century and the first half of the 19th century. The lexemes which originated in the Slavonic-Serbian epoch are analysed in the corpus Posrbica od Orfelina do Vuka by Velimir Mihajlović, with the aim of noticing the patterns of lexeme loss, along with the patterns of survival of Serbianised lexemes in the Serbian language, taking into account linguistic and non-linguistic factors which could influence language development. In comparison to the contemporary Serbian and Russian language, we can conclude that the majority of the lexemes were lost due to word-formation inconsistencies, i.e. word-formation systems which correspond more to Russian than to the Serbian language.

Key words: Serbianised lexemes, componential analysis, word-formation model, partly assimilated loan words, fully assimilated loan words, Slavonic-Serbian, Old Russian.
\end{abstract}

